\title{
Aliens in Love: Testing Bloom's Theory of the Anxiety of Influence
}

\author{
TÕNIS PARKSEPP
}

\begin{abstract}
The article aims to test the universality of Harold Bloom's theory of the anxiety of influence. Underneath Bloom's favourite tropes (Kabbalistic, psychoanalytic, Shakespearean, Miltonian, Blakean etc.) lies a diachronic system of misreading, which can be useful in analysing texts without any direct connections between them. By comparing two culturally distant but rhetorically similar prose texts, Friedebert Tuglas's short story At the End of the World (1915) and Stanisław Lem's novel Solaris (1961), this article suggests that it is possible to overcome the accustomed boundaries of national literary histories. Both of these stories depict a communication error when humans are confronted with the unknown other. The texts have alternative figures describing the alien and similar tropes presenting the human. To explore the potentiality of figurative kinship between the two authors who are strangers to each other is not an ill-fated quest, but a search, which would eventually allow us to see some hidden patterns that literary studies usually miss.
\end{abstract}

Keywords: Harold Bloom; the anxiety of influence; Stanisław Lem; Solaris; Friedebert Tuglas; At the End of the World; rhetoric; tropes; literary history

The Potential of Harold Bloom's Theory of the Anxiety of Influence

Influence and originality have long been essential matters in the literary tradition. The questions as to why we read and reread some texts and destine others to oblivion have puzzled literary scholars throughout the modern ages. Most of them agree that answers to these problems lie in the tissue of a literary work. However, in the majority of cases, it is quite hard to focus mainly on the text. Context always catches up with us. Even though facts about the writers' life and literary conditions help us to understand their texts more deeply, the same knowledge also blurs our vision when new connections between potentially similar texts. For example, the Estonian literary canon is so compact that the bulk of the interlinks between different authors were already well-set by their contemporary reviews. Of course, this is not essentially a bad thing, but it does not assist us in thinking outside the box. 
PARKSEPP

For the last fifty to sixty years, Harold Bloom has been one of the bestknown and most controversial trail-blazers on the frontiers of Western literary studies. The aim of this article is not to contribute to the endless analysis of the problematics in Bloom's theory of the anxiety of influence but to find out how useful his radical insights can be when analysing two texts from different contexts. I focus on the potentiality of his approach which is best described in one of the remarks by Alistair Heys: "Bloom thinks [Northrop] Frye irenic, and his own temperament bellicose; Anatomy of Criticism finds archetypes in common, whereas The Anxiety of Influence discovers concealed agons" (Heys 2014).

At first, drawing on Bloom's theoretical views in order to detect hidden connections between different texts may seem like an ill-fated quest. Bloom himself says that there is no other method than oneself (Bloom 1988: 425). For him, literature is not a neutral phenomenon which can be described by a scientific (or deconstructive) methodology, but an unfathomable manifestation of rival (mis)readings. Even outstanding Bloom scholars Graham Allen and Roy Sellars indicate "that Bloom's work is difficult to adopt as a methodology, and that it presents itself as a kind of literature" (Allen, Sellars 2007: XIV). Agata Bielik-Robson, whose research on Bloom is of the same calibre, adds: "The theoretical interest in Bloom waxed and waned in the ' 70 s, trying and failing to repeat fruitfully what has been said in his famous tetralogy, and since then (i.e., from the beginning of the ' $80 \mathrm{~s}$ ), there has appeared no single serious attempt to continue Bloom's speculation. This is why I do not propose here to repeat what from the very beginning was doomed to failure." (Bielik-Robson 2011: 110). She may be right, but like many other Bloom scholars, she dismisses the full potential of his insights. Underneath all of the Kabbalistic, psychoanalytic, Blakean, Miltonian and Shakespearean tropes lies a diachronic rhetorical misreading system that helps us to go beyond our usual understanding of literary evolution.

At the heart of Bloom's views on literature lie two controversial statements. On the one hand, Bloom says that "poems are written by women and men, and not by language" (Bloom 1988: 425). On the other hand, he insists that "influence anxiety exists between poems and not between persons" (Bloom 2011: 6). These statements indicate Bloom's quarrel with his deconstructionist contemporaries. Firstly, he argues that every work of literature is not merely a linguistic analogue of its other but more of a poetic document of its author's psychic evolution. This is why Bloom writes at the beginning of A Map of Misreading that "a poem is always a person" (Bloom 2003: 19) and why Roy Sellars reflects that "Bloomian theory is only psychological at all in a figurative sense” (Sellars 2007: 269). Secondly, by equating a person's psyche and a 
literary poem, Bloom stresses that a literary tradition is first and foremost a textual interaction, where the ideas of both the ephebe (successor) and the precursor collide and merge with each other. Thus, there is no singular text, but only plural texts (Bloom 2003: 3), any poem is a "rewriting" (Bloom 1976: 3) and a literary canon is formed as a diachronic two way struggle between alternative concepts of tropes (see Bloom 1977: 393) or - in other words - misreadings.

Bloom's genius lies not solely in his comprehensive analyses of different philosophical discourses or vivid descriptions of the urge for originality that drives every writer's agon for survival, but in the more fundamental ideas behind all that. According to him, the imagery of every literary text consists of an antithetical voice, which specifically means that he sees the rhetoric of each work not as a system of tropes (like Paul de Man) but as a persuasion (Allen 1994: 59; Bradley 2010: 266). Although he may dismiss English Romantics for the sake of American tradition or forget Ralph Waldo Emerson's precursor Germaine de Staël, as Mary Orr has brilliantly shown (see Orr 2010: 160, 164170), Bloom's particular views on rhetoric are still practicable. Moreover, most of the misreadings or even mistreatings of authors whom Bloom dislikes are in full compliance with the ideas of the anxiety of influence. In his unique way, he can state that Emerson is a forerunner of the English Romantics, because Bloom's theory has the potential to break the logical frame of literary history and the contextual boundaries of national canons.

Most of Bloom's critics analyse the gaps in his arguments, whereas this article aims to test the applicability of his theory to analyse the relations between works of literature. In the essence of The Anxiety of Influence is a bold section: "Antithetical criticism must begin by denying both tautology and reduction, a denial best delivered by the assertion that the meaning of a poem can only be a poem, but another poem - a poem not itself. [...] Source study is wholly irrelevant here; we are dealing with primal words, but antithetical meanings, and an ephebe's best misinterpretations may well be of poems he has never read." (Bloom 1997: 70). In the first sentence here, Bloom describes poetic influence as an interaction between the totality of different texts, but in the second sentence, he finally reveals the whole potential of his theory. I aim to take this last utterance literally and to ask: is it possible that poetic influence can occur even without any cultural or personal relationships between two authors? As I mentioned, the Estonian literary tradition is too compact for studying influence without any interpersonal connections between textually alike writers. So, the only way to escape the positivistic framework of the Estonian literary canon is to go beyond it. 
Hence, in the next part of this article I compare two rhetorically similar, but culturally distant prose ${ }^{1}$ texts: the Estonian writer Friedebert Tuglas's short story At the End of the World $(1915)^{2}$ and the Polish science fiction classic Stanisław Lem's novel Solaris (1961). But before I proceed, it needs to be underlined that the plots, the psychology of the characters and the style of these texts provide enough common ground for comparison. Also, it is highly unlikely that Lem would have known Tuglas' short story before writing his novel. So there are no visible connections between the two texts, and yet the reception of both of these stories indicates that there is enough rhetorical kinship to map Lem's misreading of Tuglas. Following Bloom's viewpoint, Lem's fantastic misinterpretation may well be of a strange short story he has never read ${ }^{3}$.

\section{Basis for Comparison of At the End of the World and Solaris}

Although the basis for a comparison between these two texts may seem farfetched, with regard to the reception of At the End of the World and Solaris, both of them deal with a human communication error when confronted with the unknown other. The most influential Tuglas scholar, Jaan Undusk, has said that At the End of the World is a "love story concentrating on love as a problem of communication" (Undusk 2005: 215). The story begins with a description of a ship's journey to the end of the world. The ship arrives at an unfamiliar and wild island where a young man is abandoned by his crew-members. Two unearthly beings live in this paradise: a giant maiden and an old giant. Even though they appear merely to be enlarged humans, they live in a symbiosis with the island and have a special ability to communicate via their eyes. Gradually the young man falls in love with the giant maiden but eventually this deep bodily affection

1 As John Hollander has indicated, Bloom reads John Milton's Paradise Lost without any line breaks as a "kind of continuous tape" (Hollander 1988: xxxvi). Therefore, the switching from poetry to prose is not as surprising as it may seem. Bloom's theoretical focus is not on questions about literary form but rather on the text's imagery and tropes, and these aspects are equally important in all of the literary genres.

2 Originally "Maailma lõpus". Translated into English by Oleg Mutt.

3 Of course, as Graham Allen has exemplified, Bloomian reading might too easily disregard all the extra-textual social and cultural codes in literary analysis (see Allen 2011: 138-140). But without testing the anxiety of influence theory on neutral ground, it is impossible to evaluate the universality of Bloom's ideas. Therefore, I have no plans for unfolding all the potential levels of these two unique works or making hasty assumptions about the writers' intentions. I just want to reiterate that great works of literature allow contradictory but equally significant readings. 
grows unbearable to him. In the heat of the moment, he kills the giant maiden and escapes from the paradise on a boat. Unfortunately, for the rest of his life, he becomes a wanderer who yearns for lost love.

The publication dates of these works are separated by nearly half a century as well as being marked by different socio-cultural conditions. Tuglas was one of the pioneers of the Estonian modernist movement and his short story was one of his attempts to introduce innovations in the style of Estonian literature. Lem's novel, on the other hand, came out during the Space Race and became one of the greatest works of science fiction ${ }^{4}$ of all time. Nevertheless, the novel's main theme overlaps with Tuglas's short story. The observations of Istvan Csicsery-Ronay, Jr confirm this: “[...] most of Solaris' commentators agree on a common reading of the novel's action and point. [...] Solaris is about the problem of whether human beings will ever be able to make contact with a truly alien intelligence, and thus transcend the anthropomorphism and anthropocentrism apparently inherent in human cognition" (Csicsery-Ronay, Jr 1985: 7). On this basis, the human condition in Solaris is starting to resemble the cognitive error that Jaan Undusk describes in At the End of the World where "a young man $[. .$.$] from a sign centered situation [...] steps into a magical reality"$ (Undusk 2005: 218).

Solaris is a mysterious planet, which is mostly covered with one sentient but incomprehensible ocean-like substance or organism. Humans have studied it and its strange surface formations for decades and still have no clue as to what they are facing. The story begins with the protagonist, the psychologist Kris Kelvin's arrival at the Solaris station to find out whether research on the planet has made any progress. Slowly he discovers that a significant change in the communication with the ocean happened after it was bombed with X-rays. Out of nowhere, all of the stationed scientists meet the incarnations of their deepest and most traumatic memories. Kelvin is rejoined by the embodiment of his lost lover, Harey ${ }^{5}$. She appears the same as her original, but she has no memories of her suicide, is indestructible and cannot leave Kris's side. Gradually he falls

4 There is no doubt about Bloom's fondness for science fiction. He has written a Gnostic fantasy himself, The Flight to Lucifer (1979), and in his later career he has even considered Milton's Paradise Lost as a version of science fiction (Bloom 1993: 26). For him, fantasy and science fiction is "a belated version of romance" that "promises an absolute freedom from belatedness" and "from the anxieties of literary influence and origination". Its only downfall is that it can go too far with its imaginative power, leading up to a nightmarish situation (Bloom 1982: 206).

5 Because, since 2011, there is finally a direct English translation of Solaris (made by Indiana University professor Bill Johnston), some of my quotations may seem a bit different (yet more accurate) compared to the most common translation by Joanna 
in love with her and in spite of the insurmountable disparity between them, he starts to dream of their happy life together back on Earth. In an ironic plot twist, she (re)commits suicide for her lover's sake. Thus, Kris feels he has no home any longer and continues his quest on Solaris.

My central argument in the next pages is that even though the cultural contexts, style or plots of Solaris and At the End of the World do not overlap, the texts' similar themes indicate that they have a similar rhetorical foundation. But are kindred subject matters enough for us to be able to speak about poetic influence? To test the validity of my assumption, I use Bloom's figurative influence-tracking system that he calls a map of misreading (in a work of the same name). Although this methodological layout of revisionary ratios, or in other words a Scene of Instruction, is a mixture of different contexts (such as Kabbalah and psychoanalysis), it is based on a rhetorical system of six tropes (see Bloom 2003: 84). Bloom got the idea to describe his ratios in a rhetorical way from Paul de Man's review of The Anxiety of Influence. In short, there De Man illustrates how a writer's great agon for originality is nothing more or less than a sixfold figurative turn on the grounds of language (De Man 1983: 275). And precisely this dispute with De $\mathrm{Man}^{6}$ makes Bloom's insight into poetic influence a prolific one.

For De Man, literature was an endless figurative "turn towards error" (De Man 1979: 113). While he was talking about the unreadability that any text (analogically) produces (see Moynihan 1986: 148), Bloom argued on behalf of individual misreading. It is a notion about how we perceive literature, and it is derived from his understanding that tropes are figures of will (Bloom 2003: 93; Hollander 1988: xxxii). In Bloom's opinion, this Demanian linguistic error is dependent on the characteristics of the human psyche. Every writer (and therefore text) tries to defend its own views and to absorb others'. De Man's more synchronic viewpoint, whereby texts act like unstable entities, and every attempt to systematize them is a form of linguistic falsification, is met with Bloom's understanding that we use tropes for a reason, we want them to do something for us (see Bloom 1982: 31). Therefore, according to the anxiety of influence, it is possible to describe literary evolution as a diachronic two-way

Kilmartin and Steve Cox (Walker \& Co, 1970). All the names in this article are given as in the original Polish version: so Rheya is again Harey, and Snow is Snaut.

6 Bloom's agon with deconstruction is somewhat similar to his disputes with the New Critics and with his precursor proper, Northrop Frye. For Bloom, seeing a literary tradition as an organic whole and an ideal order of anagogues or archetypes is an illusion. Concealed relationships between poets' imagery are always present. Consequently, the literary canon cannot merely be a neutral system (see Heys 2010: 48-58). 
interaction, where a latecomer's text corrects and repeats the forerunner's work. Bloom clarifies thus: "What matters is not the exact order of the ratios, but the principle of substitution, in which representations and limitations perpetually answer one another" (Bloom 2003: 105). Thus, to comply with the anxiety of influence, Solaris would need simultaneously to limit and to re-enact ${ }^{7}$ At the End of the World's figurative plurality. In the following pages, I demonstrate this substitution (firstly the revisionist movement against and secondly for parent imagery) in detail.

\section{Different Aliens or Tropes of Limitation}

The testing of Bloomian views on poetic influence starts with charting the tropes by which the latecomer's text limits the forerunner's work: irony, metonymy and metaphor ${ }^{8}$. Bloom describes these conceptual movements away from previous meaning(s) by means of verbs: to withdraw, reduce and curtail (see Bloom 2003: 94-95). In summary, these rhetorical shifts illustrate the step-by-step elaboration of everything immanent in the latecomer's text. For Bloom, this is the part where an ephebe's agonistic contraposition or "contest for aesthetic supremacy" begins (Bloom 1997: xxiv). So to argue that Solaris and At the End of the World are somewhat rhetorically related, we first need to describe the ephebe's firm movement away from the predecessor and towards independent imagery.

To survey the main difference between these works, we need to undestand the essence of Tuglas's storytelling. In writing about the creation of At the End of the World, he stresses that all of the unrealistic and fantastic content of the story needed to emerge from traditional knowledge and reality (Tuglas 1973: 88-89). This is the reason why Ilmar Talve describes Tuglas's paradise island as an antipode or mirror of the human world (Talve 2008: 146). When Tuglas

This two-way movement is precisely what differentiates Bloom's theory from the usual understanding of influence and allusion. For example, it is common knowledge in Estonian literary studies that the inspiration for Tuglas's novella was partly a story called The Voyage to the End of the World from our national epic Kalevipoeg: "This is where your boy went straying / Lured there by the naiad maidens, / In contentment never ending / Happily to live e'er after" (Kreutzwald 2011: 385). So according to Bloom's theory, when Tuglas borrows different motifs from earlier texts, this may be an area of interest to source study, but it is not in Bloom's theoretical focus (see Bloom 1997: 7). Rather, he is obsessed with the question of how the rhetorical imagery of this whole text interacts (back and forth) with the wholeness of the other.

8 To prevent further misunderstandings of the anxiety of influence, I try to be as compact as possible in outlining the essential matter in Bloom's theory. 
describes the other, he binds it together with the common. For Ants Oras, it is the logical frame that restrains the mythological mindset (Oras 1997: 3031). But as Elo Lindsalu has shown, Tuglas's descriptions are more akin to the traditional patterns of thinking in Western culture, where man and woman, culture and nature, self and other are binary oppositions (see Lindsalu 2005: 151).

Similarly to Tuglas, Lem is concerned with the philosophy behind the act of writing. But unlike his predecessor, he is more interested in the semantic bendings of narrative structures: "In practice, it is often impossible to determine whether a given narrative structure is only very indirect and elliptical, but essentially homogeneous, or one deliberately damaged by 'chance noise', or even perforated, softened, and bent by another, discordant structure" (Lem 1984). As Csicsery-Ronay Jr. writes, Lem "conflates these two ways of creating semantic indeterminacy in the design of his novel" (Csicsery-Ronay, Jr 1985: 15). Therefore, it is possible to suggest that the traditionalism of Tuglas's novella finds its figurative end in Lem's novel. Solaris is just too unconventional a story, such that proper adjectives describing it are "indecisive" and "obscure". The portrait of the alien ocean-like substance does not rely on the familiar, but tries to find its own personal expression. Carl Freedman remarks: "From the Lemanian standpoint, the chief philosophical enemy is positivism; that is the dogmatic assumption of an unproblematic and invariably positive adequation between knowing subject and known object." (Freedman 2000: 98) Basically, Solaris corrects its precursor's views. In contradistinction to Tuglas's short story, Lem's novel withdraws the determinate binary system of known/unknown and replaces it with an ironical instability guided by the endless questions over our ability to understand or describe the truly other.

The juxtaposition of these two works of literature lies at the heart of their setting. The location of Tuglas's story is a paradise island, where everything is strange but somehow familiar: "The vegetation seemed familiar, nevertheless, strange upon closer examination. There were delicate shrubs resembling birches covered entirely with pink blossoms. The moorworts were tall as pinetrees. The oaks had needles black as iron" (Tuglas 1982: 67, hereafter EW). Lem's novel, on the other hand, designates the strange formations of Solaris' ocean using artificial names like "extensors", "symmetriads", "asymmetriads", and "mimoids". The narrator questions the usual way in which humans understand the world: "Was thinking without consciousness possible? Yet could the processes that took place in the ocean be regarded as thought? Is a mountain a very large rock? Is a planet a huge mountain? These terms can be used, but the new scale of magnitude brings with it new regularities and new phenomena." (Lem 2017; hereafter S) All Solaris' formations are unique, so it is impossible 
to grasp them adequately. They form a truly new phenomenon, and even though it is debatable if this shift away from the philosophy of Tuglas is solely a Bloomian ironic withdrawal, it cannot be denied that Lem painfully points out the limitations of our all-too-anthropocentric scientific thinking.

Further development of the rhetorical "emptying-out" (see Bloom 1997: 14) of Tuglas's imagery is found in the descriptions of female characters. While the giant maiden in At the End of the World is a beautiful god-like human who can read minds and blend in with nature, Harey in Solaris is the indestructible product of the ocean (made of Kris Kelvin's memories of his long-gone lover). At first, these characters may seem incomparable, yet metonymic substitution is always only a partial shift and never as clear as irony. Instead of the giant maiden, whose eyes hide a "bottomless depth" and who is everywhere or in everything (EW: 76; 79-80), we meet Harey whose blood consists of a "silver emptiness" and whose thoughts come "further away" (S); not to mention the fact that she cannot leave Kris's side. In the eyes of Tuglas's young man, the giant maiden appears to be both "new each time" and as "old as if [he] had seen her in some other life" (EW: 76). Harey, on the other hand, is a projection of Kris's reminiscences of their past life together and reappears after Kelvin sends her first copy to space. Therefore, both of these women represent, in an alternative way, the alien's familiar or unfamiliar characteristics. But in accordance with Bloom's theory, the young sailor's relationship with the divine other is, in Solaris, rhetorically reduced to the limited connection with the unknown. "Even though Kelvin can communicate with Rheya [=Harey] because, by design, they occupy similar noetic sub-levels, his hopes of communication with the ocean itself seem to be forever doomed; the ocean is high and outside our window of contact" (Weissert 1992: 164).

The third level of Lem's figurative agon against Tuglas is traceable in how both stories present the culmination of the alien's love. For Bloom, this "is the contest proper, the match-to-the-death with the dead" (Bloom 1997: 122). The sexual interaction between the man and the maiden leads Tuglas's protagonist to the following understanding: "A human being can love only another human being. The love of a giant spells death for a human" (EW: 82). Even if Solaris' anthropocentrism is equally uncanny, the love between Kris and Harey is considerably different. Harey tries to kill herself with liquid oxygen and defines herself as Kris's torture implement "that could have good intentions and could love" (S). Hence, the overwhelming godly bacchanal that started in At the End of the World finds its metaphorical curtailment in Solaris as an existential agony over the possibility of love between aliens. Paradise's "dreadful temple of desire" (EW: 84) is in Solaris a "dark, unlit stage" within Kris (S). And even though both stories have bloody spectacles (in a deep forest and on the surface of the 
ocean) that look somewhat alike, their culminations are distinctively different, and this difference is the most important factor here. While the sailor murders the godly creature for the sake of his survival (EW: 86-87), Harey accepts her end freely: "Darling, it was me who asked him to do it. He's a good man. It's awful that I had to deceive you, but there was no other way" (S). The reason for this inescapable situation resides in the completely opposite methods by which these authors narrate their stories. For Tuglas, the giant maiden's love is too big and grows unbearable for the young man. At the same time, Lem tropes against this view and shows the improbability of the whole idea of a happy relationship between a human and the other. In accordance with the anxiety of influence, even the dream of love is dead.

As Kelvin admits: "Contact means an exchange of experiences, concepts, or at least results, conditions. But what if there's nothing to exchange? If an elephant isn't a very large bacterium, then an ocean can't be a very large brain" (S). Tuglas's depiction of the other meets its metaphorical impasse - that is, what if there is nothing to exchange? In the last part of this article, I examine how this problem of contact is represented similarly in both of these stories, and how Lem absorbs Tuglas's imagery to become a true original. For the anxiety of influence to take place, there also needs to be a threefold figurative reiteration, where the echoes of the forerunner's tropes can be found in the ephebe's text.

\section{Same Humans or Tropes of Representation}

While the first part of this analysis showed how tropes as irony, metonymy and metaphor are used to revise or correct the forerunner's text, the second part of this experiment is to exemplify how tropes as synecdoche, hyperbole and metalepsis assist the ephebe's writing in becoming a truly original work of literature. These three tropes symbolise the poet's figurative swerve toward the tradition or becoming a predecessor. Bloom describes them as movements to enlarge, heighten and overcome temporality (see Bloom 2003: 95). In terms of rhetoric, this is the part where the rewriting of the historical context is finally possible, and Solaris should step up beside or even exceed At the End of the World. In my opinion, these tropes of representation come in handy when we compare the standpoints of the two protagonists in the course of their narratives.

Every thorough communication act always starts with grasping the situation. That being so, the first trope of representation, or a figurative part for a whole movement, can be seen when we compare the explorations of the young sailor and Kris Kelvin. This should be the segment where the ephebe 
"antithetically 'completes' his precursor" (Bloom 1997: 14). In chapter five, the young sailor describes how he followed "the sheep tracks" and "got acquainted with the island" (EW: 66). Soon he gets lost on his way through "the darkness of the woods" and stumbles into a "rocky glen" (EW: 67). Finally, he states: "I tried to understand the life around me, but my thoughts made no progress." (EW: 68) The same situation is noticeable in Solaris. To understand the alien ocean and the "G-formations", Kris Kelvin tries to work through the endless tracks of Solaristic hypotheses. He hopes to find the meaning in all this, but is still unable to find a single answer to a child's question: "What's it all for?" (S) Everything in their quest is futile and young man's misunderstanding in At the End of the World is extended in Solaris to encompass humanity's needs and purposes: "We're not searching for anything except people. We don't need other worlds. We need mirrors. We don't know what to do with other worlds." (S)

The second step of figurative representation, or the situation where a later writer "opens himself to the power of parent" text (Bloom 1997: 15), is hidden in the socializing process between humans and aliens. The interaction with their respective female partners goes through similar stages for both protagonists. At first, both heroes reject the other, the young man hurts the giant maiden with a sword (EW: 60) and Kris Kelvin sends the first copy of Harey off to space: "At that point, from the loudspeaker now connected to the rocket's interior there came a half-whimper, half-whistle that was utterly unlike any human voice, despite which I could make out in it a repeated howl: "Kris! Kris! Kris!!”' (S) In summary, the next steps can be described as follows: confusing the women with dream products, acclimatizing oneself to the reality of a foreign situation, and finally - falling in love. But on closer examination, we can see that both protagonists patronise the women. Sometimes childlike attributes are added when the males address the female characters. The young man gives the following description: "She was like a child. She let me do what I wanted with her. And the more harm I did to her, the more grateful she was." (EW: 77) Kelvin, on the contrary, makes Harey snap: "I don't want you to talk like that. I don't want it, you hear? I'm not a kid. I'm..." (S) At other times both men are in emotional turmoil. This may manifest itself as an attempt to flee from the island (EW: 81) or as heightened mental pain: "Kris!" / "What?" / "I love you." / I felt like screaming." (S) All in all, this is a corresponding rhetorical movement, but the traditional physical battle of the sexes in At the End of the World (see Lindsalu 2005: 151) is replaced with a hyperbolical objectification in Solaris, as the female character is "the product and property" of the male mind (Helford 1992: 174).

Next to irony (as the figure of the first revisionary ratio), the most important trope to Bloom is the last one, metalepsis. As Graham Allen writes, the 
rhetorical device of the sixth revisionary ratio is representing a "reversal and disruption of the logical order" (Allen 2010: 152). Although metalepsis is both a rhetorical trope and a narratological category, most of the definitions imply some kind of interruption in the logical frame (see Hanebeck 2017: 11-23). To Bloom, this enables us to change the arrangement of literary history or to show "moments in which the dead may return" (Allen 2010: 152). In relation to the analysis of Tuglas and Lem, this indicates the possibility that, on a rhetorical level, Lem becomes Tuglas's precursor'.

When we concentrate on the final sections of At the End of the World, we are faced with the young man's sad declaration: "Are we human beings? No, we are but children, silly, moody children. Real people live somewhere else, on those distant islands. I have seen them. [...] they were still so big as to be unbearable to us. An eternal longing remained in me. My heart was broken in two and nothing could mend it again. I know how feeble I was among the giants, but I could not find my place among human beings either." (EW: 88) According to Jaan Undusk, this emotional twist into two is describable by means of the trope of oxymoron. It is the co-existence of opposites like "God and man, word and thing, flesh and soul” or "midnight sun" (Undusk 2005: 212-213; EW: 78). It is the figurative end of Tuglas's story and a symbolic trope for any synchronic interpretations.

The ending of Solaris' is somewhat similar. Lem's Kris also states that he has lost the contact with other humans and has "no home" (S). But his thoughts trancend the precursor's protagonist's "eternal longing” for the giant's divinity. Kelvin understands that staying on Solaris leaves him a "perhaps a slim, perhaps an only imagined chance" (S) of making contact. Yet, he has no hope for that. To him, Solaris is beyond the rationality of humankind. It is not humans or Solaris' ocean who are childlike but maybe the whole situation itself. As Snaut says: "Perhaps Solaris is precisely the cradle of this divine infant of yours," and "Perhaps in your conception this is the origin, the seed of the God of despair, perhaps its exuberant childhood is way beyond our comprehension, and everything our libraries of solariana contain is merely a catalogue of his infant

9 For Bloom, who in his later career speaks more and more about the "aesthetic supremacy" of William Shakespeare and is vividly against historicizing the great works of literature (Bloom 1993: 23), becoming free from the restraints of the historical order is of utmost importance. It helps Bloom to keep his focus on the textual categories, and although it is debatable what an aesthetic supremacy should really be or what a romantic quest for becoming one's own "Great Original” (see Bloom 1997: 64) should actually look like, the plea is understandable. Without the determinacy of time and context, the texts are rivals on fair grounds. Who comes first (or writes on the right topics) becomes irrelevant compared to the question of who writes better. 
reflexes..." (S). This vision of the God of despair providing us with different infant reflexes and nothing significant is exactly the metaleptic disruption of the logical oxymoronic order of Tuglas. Moreover, the figurative vagueness of the ending of Solaris' allows us to read history backwards - as if Tuglas's story would have rhetorically adjusted the uncertainty of Lem's novel and replaced it with the more fathomable short story ${ }^{10}$. This means that the "wheel has come full circle" (Bloom 1997: 15-16) and the determinism of literary history is finally shattered.

\section{Conclusion}

Although this experiment confirms that it is (at least to some extent) possible to use Bloom's ideas as a systematic methodology, his rigour towards traditional accounts of allusion or intertextuality needs to be explained. Literary history, as the anxiety of influence would also imply, does make use of the discoveries of common source study. The search for "primal words" (see Bloom 1997: 70) does not actually dismiss the traditional accounts of motifs and themes as "wholly irrelevant". In reality, then, Bloom's writings somewhat overlap with Northrop Frye's archetypal criticism and can be (mis)read as just another account of the evolution of genre conventions. But the way in which Bloom describes the tradition is utterly different from Frye or any other contemporaries of him. In accordance with the anxiety of influence, the literary tradition is a textual battleground where all the tropes agonistically and antithetically rival each other. Although the analytical starting point for Bloom may still be traditional (as the science fiction genre conventions are in my comparison), the analysis itself is performed in a unique way and allows us to make remarkable discoveries. Bloom emphasizes the figurative or tropical nature of any literary interactions. No matter that he has burdened his writings with sundry and enigmatic contexts; his theory presents a real possibility to overcome the canonical boundaries of national literature and to track the development of world (or at least Western) literature.

10 The main criticism of this analysis may well come from Paul de Man. From a Bloomian standpoint, it is really hard to argue that rhetoric as persuasion is not deconstructed by rhetoric as a system of tropes (see De Man 1979: 131) or that this comparison is something more than an endless swirl on the grounds of language. Therefore, the idea of Lem becoming a forerunner of Tuglas might altogether be based on a false assumption. But it may also be just one concept of tropes next to all the others (see Bloom 1977: 393). For example, see Mark Rose's speculations about the similarities between Lem's, Jules Verne's and Herbert George Wells' fiction (see Rose 1981: 121-42). 
PARKSEPP

In conclusion, Bloom's theory might appear to be something not so completely different from the practice of "patterning images" that he dismisses (Bloom 1997: 7), but he distinctively emphazises the diachronic figurative nature of the development of imagery. Hence, regardless of the validity of his claims about genuine criticism, Bloom gives a new perspective on understanding how literary tradition is formed. Despite the fact that Tuglas's and Lem's texts construct the alien considerably differently, they make the human go through a similar torment.

\author{
Tõnis Parksepp \\ tonisparksepp@gmail.com \\ c/o Interlitteraria \\ Ülikooli 16-113 \\ 51003 Tartu \\ EESTI / ESTONIA
}

\title{
References
}

Allen, G. 1994. Harold Bloom. A Poetics of Conflict. New York, London, Toronto, Sydney, Tokyo, Singapore: Harvester Wheatsheaf.

Allen, G. 2010. Apophrades, Adonais, and the return of the Shelleys. - A. Raves, J. Sears, eds., Reading, Writing and the Influence of Harold Bloom. Manchester, New York: Manchester University Press, 133-155.

Allen, G. 2011. Intertextuality. 2. Ed. London, New York: Routledge.

Allen, G., Sellars, R. 2007. Preface. Harold Bloom and Critical Responsibility. R. Sellars, G. Allen, eds., The Salt Companion to Harold Bloom. Cambridge: Salt Publishing, xiii-xxviii.

Bielik-Robson, A. 2011. The Saving Lie. Harold Bloom and Deconstruction. Evanston, Illinois: Northwestern University Press.

Bloom, H. 1976. Poetry and Repression. Revisionism from Blake to Stevens. New Haven, London: Yale University Press.

Bloom, H. 1977. Wallace Stevens. The Poems of Our Climate. Ithaka, London: Cornell University Press.

Bloom, H. 1982. Agon. Towards a Theory of Revisionism. New York, Oxford: Oxford University Press.

Bloom, H. 1988. Coda: The Criticism of Our Climate, a Self-Review. - J. Hollander, ed., H. Bloom. Poetics of Influence. New Haven: Henry R. Schwab, 425-430.

Bloom, H. 1993. Western Canon. New York, San Diego, London: Harcourt Brace \& Company.

Bloom, H. 1997. The Anxiety of Influence. 2. Ed. New York, Oxford: Oxford University Press. 
Aliens in Love: Testing Bloom's Theory of the Anxiety of Influence

Bloom, H. 2003. A Map of Misreading. 2. Ed. New York, Oxford: Oxford University Press.

Bloom, H. 2011. The Anatomy of Influence. New Haven, London: Yale University Press.

Bradley, A. 2010. The impossibility of reading: Bloom and the 'Yale School' of criticism. - A. Raves, J. Sears, eds., Reading, Writing and the Influence of Harold Bloom. Manchester, New York: Manchester University Press, 259-282.

Csicsery-Ronay, Jr, I. 1985. The Book Is the Alien: On Certain and Uncertain Readings of Lem's "Solaris". - Science Fiction Studies, Vol. 12, 1, 6-21.

De Man, P. 1979. Allegories of Reading. New Haven, London: Yale University Press.

De Man, P. 1983. Blindness and Insight. 2. Ed. by W. Godzich. Minneapolis: University of Minnesota Press.

Freedman, C. 2000. Excurses. Solaris: Stanisław Lem and the Structure of Cognition. - Critical Theory and Science Fiction. Middletown: Wesleyan University Press, 94-111.

Hanebeck, J. 2017. Understanding Metalepsis. The Hermeneutics of Narrative Transgression. Berlin, Boston: Walter de Gruyter.

Helford, E. R. 1992. "We Are Only Seeking Man”: Gender, Psychoanalysis, and Stanislaw Lem's "Solaris". - Science Fiction Studies, Vol. 19, 2, 167-177.

Heys, A. 2010. The decline of America: Bloom's monumental theory of history. A. Raves, J. Sears, eds., Reading, Writing and the Influence of Harold Bloom. Manchester, New York: Manchester University Press, 48-70.

Heys, A. 2014. The Anatomy of Bloom. Harold Bloom and the Study of Influence and Anxiety. New York, London, New Delhi, Sydney: Bloomsbury Publishing Inc [ePub].

Hollander, J. 1988. Introduction. - J. Hollander, ed., H. Bloom. Poetics of influence. New Haven: Henry R. Schwab, xi-xlvi.

Kreutzwald, F. 2011. Kalevipoeg. The Estonian National Epic. Trans. by T. Kartus. Tartu, Tallinn: Estonian Literary Museum.

Lem, S. 1984. Microworlds. Writings on Science Fiction and Fantasy. Ed. by F. Rottenteiner. San Diego, New York, London: Harcourt Brace and Company [Kindle Edition].

Lem, S. 2017. Solaris. Trans. by Bill Johnston. Krakow: Pro Auctore Wojciech Zemek [Kindle Edition].

Lindsalu, E. 2005. - Male and Female at the End of the World. - R. Undusk, ed., At the End of the World. Text, Motif, Culture. Tallinn: The Under and Tuglas Literature Centre, 142-153.

Oras, A. 1997. Friedebert Tuglase ilukirjanduslik looming. Kriitiline etüüd. Tartu: EÜS Veljesto kirjastus.

Orr, M. 2010. Towards a feminist revisionism of an aesthetics of mastery: Bloom, neoRomanticism and the critical sublime. - A. Raves, J. Sears, ed., Reading, Writing and the Influence of Harold Bloom. Manchester, New York: Manchester University Press, 156-175.

Rose, M. 1981. Filling the Void: Verne, Wells, and Lem. - Science Fiction Studies, Vol. $8,2,121-142$. 
PARKSEPP

Sellars, R. 2007. Harold Bloom, (Comic) Critic. - R. Sellars, G. Allen, ed., The Salt Companion to Harold Bloom. Cambridge: Salt Publishing, 255-289.

Talve, I. 2008. Maailma lõpus. - Vanem ja noorem Eesti. Tartu: Ilmamaa, 138-153.

Tuglas, F. 1973. Rahutu rada. Elu-ja kirjandusloolist. Tallinn: Eesti Raamat.

Tuglas, F. 1982. At the End of the World. - Riders in the Sky. Trans. by O. Mutt. Tallinn: Perioodika, 50-89.

Undusk, J. 2005. The Untranslatability of Body: Remarks on Language in the Extreme. - R. Undusk, ed., At the End of the World. Text, Motif, Culture. Tallinn: The Under and Tuglas Literature Centre, 200-224.

Weissert, T. P. 1992. Stanislaw Lem and a Topology of Mind. - Science Fiction Studies, Vol. 19, 2, 161-166. 